\title{
Development of Professional Communication Skills in Students in the ESP Class: Integration of Communicative and Critical Thinking Approaches
}

\author{
Irina Kulamikhina \\ Foreign Languages Department \\ Omsk State Agrarian University named after P.A. Stolypin \\ Omsk, Russia \\ irakula@yandex.ru \\ Olga Samylova \\ Developmental and Pedagogical Psychology Department \\ Shadrinsk State Pedagogical University \\ Shadrinsk, Russia \\ Olgas2770@yandex.ru
}

\author{
Elena Kamysheva \\ Foreign Languages Department \\ Russian State University for the Humanities \\ Moscow, Russia \\ ejkamysheva@yandex.ru
}

Anzhelika Balobanova

Foreign Languages Department

Novosibirsk Military Institute of National Guard Troops

Novosibirsk, Russia

balolika@mail.ru

\author{
Evgeniya Rakhmetova \\ Foreign Languages Department \\ Novosibirsk State Technical University \\ Novosibirsk, Russia \\ rahmetova89@mail.ru
}

\begin{abstract}
The present study is aimed at checking the efficiency of the four thinking-based communicative teaching strategies: guided discussions, role-based group work, the use of thinking maps, creative writing for developing professional communication skills in veterinary undergraduate students in the ESP class. These strategies were used to instruct a 72-hour ESP course at Omsk State Agrarian University. The comparative analysis of students' performance in the experimental and control groups in the end-course examination and direct teacher observation in class allows the conclusion about the efficiency of the implemented strategies. The study produced several findings. 1. If students are equipped with the thinking mapping strategy and the creative writing 4-step management strategy, they perform better in reading, writing, and speaking and they are more organized in learning. 2 . The role-based group work proved to be the most effective in relation to practicing reading, speaking and listening skills. 3. Although a guided discussion was really an effective strategy to engage students into intellectual communication, there is still the need for further development in all-level communication engagement of the students. 4 . The traditional teaching methods such as grammar and vocabulary drills proved to be more beneficial for mastering grammar structures and profession-related terminology.
\end{abstract}

Keywords - professional communication skills, communicative approach, critical thinking approach, teaching strategy, ESP class

\section{INTRODUCTION}

In the $21^{\text {st }}$ century, along with other soft skills like critical thinking, teamwork, leadership, social intelligence, good communication is essential for successful career in any area.
Development of professional communicative competence makes university graduates highly competitive in the job market [1]. Effective professional communication skills are integral to the profession of a veterinary doctor as this work involves a lot of interaction with other veterinary personnel, consultation of animal owners and farmers, collaboration with veterinary and sanitary authorities, etc. Moreover, with good English communication skills, veterinary doctors can participate in professional mobility programmes to improve their career prospects.

Equipping university students with well-developed professional communication skills is one of the most important aims of higher educational institutions. However, it is worth mentioning that there has been a long ESP teaching tradition in Russian universities according to which the English language has never been considered as a means of communication, but as a means of understanding texts on professional topics. That is why the read-and-translate approach to profession-related foreign language study has domineered in most non-linguistic universities. Students usually focus on memorizing materials for exams rather than trying to understand how to apply the learning materials in different academic and professional situations. This traditional teaching concept is no longer adequate to enable students to skillfully use the obtained language skills in different profession-related communication situations. There is a need to revise traditional approaches to ESP teaching in nonlinguistic universities. 
The analysis of English teaching practices at the Omsk State Agrarian University (OmSAU) in the recent 5 years provides the understanding of the importance of innovative classroom management strategies for creating a special motivating environment for the language study [2], [3], [4]. One of the main reasons for low motivation in students is the absence of visible uses of English in the future profession. It is often challenging to get students motivated in the ESP classroom when they do not experience the direct need to apply English to their professional and social life. The teachers have to find creative ways to solve the problem of students' low motivation in developing their communication skills. We assume that teaching practices should be modified by way of infusing critical thinking and meaning in language teaching. When students are engaged in thinking, they are more motivated to communicate ideas and to acquire language to communicate, which will enhance students' academic performances in general [5], [6].

We suppose that if the teachers use the specially chosen teaching strategies incorporating principles of communicative and critical thinking approaches in the instruction of the ESP course, undergraduate students will be more successful in gaining professional communication skills.

The present study aims to check the efficiency of thinkingbased communicative teaching strategies for developing professional communication skills in veterinary undergraduates in the ESP class.

\section{MethodOLOGY}

When it comes to teaching English for specific purposes, teachers have employed different teaching approaches such as the grammar translation approach, the lexical approach, the audio-lingual approach, the reading approach, the structural approach, which are considered to be traditional in the language teaching [7]. Other innovative approaches have been developed and successfully used in the language teaching recently: the visual-based approach, the situational approach, the ICT-based approach, the thinking based approach, etc. However, the most commonly used is communicative approach [8].

According to D. Larsen-Freeman \& M. Anderson and L. Wei, the communicative approach to language teaching includes the following characteristic features: the communicative purpose of activities; the use of communication-based activities such as games, role plays; the use of authentic materials as a communication stimulus; interactive group work; inductive learning of grammar; student-centered classroom; the facilitating role of the teacher in class; the balanced development of four language skills [8], [9].

The main distinction between the thinking-based approach and the traditional approach to language teaching is that with the first one, the teachers instruct students how to think effectively when they learn or practice language rules or skills meaningfully, so that further they can perform competently in communication situations [10]. Also, with this approach, students learn how to use different thinking skills (Bloom's Taxonomy thinking skills) in the process of learning [11].
Thinking-based learning method explores, provokes, and probes learning potential of the learners in order for them to become self-directed and intrinsically motivated learners; this then allows them to transfer the experiences they gained into future life [12].

The critical-thinking-based approach to language teaching is based on some major ideas such as meaningful language learning, activity-based learning, teacher-students thinkingbased interaction in the classroom, cooperative learning, the use of thinking organizers in the classroom.

Meaningful language learning means intellectual and emotional engagement of students when they acquire new knowledge and develop skills [13]. Activity-based learning makes the focus of attention of the teachers and students on the learning materials and tasks, which makes students responsible for their learning outcomes. Cooperative learning supports meaningful communication between students. Moreover, learning new knowledge or skills in cooperation, they can benefit from each other's experience and abilities. They can ask one another for explanation or clarification of information, evaluate one another's works [14]. Besides, students in cooperative learning settings compared to individualistic or competitive learning settings, achieve better results and gain higher self-esteem [15]. Using thinking organizers in the classroom, teachers show the students how to think in a deeper way. Such tools as thinking maps, graphics, PMI serve as motivators and organizers of higher-order thinking (analysis, synthesis, or evaluation) [16], [17], [18].

The combination of the communicative and critical thinking approaches in the ESP classroom is expected to produce a positive change in students' academic achievements resulted in lessening reading and translating skills emphasis and moving to the development of critical thinking and balanced professional communicative skills in reading, listening, speaking and writing. The mastery of linguistic aspects such as grammar and profession-related terminology is to be used to support professional communicative skills. The organization of the learning materials is based on topical themes and language skills but not on the linguistic aspects. The assessment of professional communication skills is integrated into the communication tasks. It involves the assessment of the linguistic knowledge (grammar and vocabulary) in the context, and practical language skills (listening, reading, speaking and writing) used with a certain communicative purpose in profession-related settings.

\section{RESEARCH PROCEDURE}

Our research questions are: 1) What are the specific thinking-based communicative teaching strategies to engage students into thinking-based communicative language learning? 2) What are the benefits of these strategies for the language instruction in the ESP classroom? 3) Will the students in the experimental group gain better professional communication skills at the end of the course than the students in the control group? 
The following research methods were used to map the difference in students' outcomes in the experimental and control groups: direct observation, questionnaire method, pedagogical diagnostics, testing, assessment of students' performance in the exam.

\section{Research samples: participants, settings}

The present study was carried out in the second term of the academic year of 2018-2019 at OmSAU. The participants in this study were first-year undergraduate students majoring Veterinary Medicine: 36 participants in the experimental group (Group1) and 34 participants in the control group (Group 2).

The instruction of the 72-hour ESP course for the control group of students was traditional with the main focus on reading and translating texts on professional topics, drilling terminology from the texts and mastering grammar structures by completing grammar exercises.

In the experimental group, the ESP course was instructed by implementing the four strategies incorporating both communicative and critical thinking principles: 1) Guided discussions; 2) Role-based group work; 3) The use of thinking maps; 4) Creative writing (summaries, essays, descriptions).

Now, we will consider the benefits of each strategy from the point of view of its communication and critical thinking potential and, then, describe how we used these strategies for developing professional communication skills in students while delivering the ESP course.

A guided discussion is a teaching strategy which encourages both communication and critical thinking in the classroom. It was used when preparing students for a writing assignment or as a pre/after-reading or pre/after-watching activity in the classroom. Also, teachers organized guided discussions as independent activities. As students participated in the discussion, they demonstrated their knowledge and understanding of the course topics, developing a deeper comprehension of the material. The teachers chose a thought provoking written or media text on a profession-related topic or a meaningful image related to the topics under study, and prepared questions to guide a discussion. Using Bloom's Taxonomy, the teachers developed all-level questions (knowledge, comprehension, application, analysis, synthesis, and evaluation to engage students into the low-order and higher- order thinking about the language and the topic. For example, at the knowledge level, the students were asked to recall some information about grammar rules, or terminology, or background knowledge to be used in the discussion. At the comprehension level, the students had to demonstrate that they understood the meaning of the terminology, or the content of reading/listening activities by means of answering comprehension questions or summarization of the text. At the application level, the students were requested to demonstrate how they could use the acquired knowledge or language skills in a new situation related to the topic. Analysis-level questions encouraged students to break the material into parts, describe relationships among parts. At the synthesis level, the questions helped students to create new ideas by using the information from the text or other sources. Evaluation questions encouraged students to develop opinions about issues raised in the discussion.

Here is an example of the list of guiding questions to the discussion on the topic "Companion animals vs service animals". The discussion followed a short animated film "The Present" by Jacob (https://www.youtube.com/watch?v=WjqiU5FgsYc). This strategy was used as an after-watch activity.

TABLE I Examples of Guiding Low-Order and Higher-Order Thinking Questions

\begin{tabular}{|c|c|}
\hline Thinking level & Example questions \\
\hline Knowledge & $\begin{array}{l}\text { "What is a companion animal?" "What companion } \\
\text { animals do you know?" "In what ways can the dog help } \\
\text { the man?" "In what ways can the dog serve the man?" } \\
\text { "How would you describe the dog in the film?" "How } \\
\text { did the dog help the boy in the film?" }\end{array}$ \\
\hline Comprehension & $\begin{array}{l}\text { "Can you describe the plot?" "Can you summarize the } \\
\text { main ideas of the film?" "Can you explain why the boy } \\
\text { is obsessed with computer games?" }\end{array}$ \\
\hline Application & $\begin{array}{l}\text { "How will the life of the boy change after he has a dog?" } \\
\text { "What other companion animals could help the boy } \\
\text { change his life? Explain how." }\end{array}$ \\
\hline Analysis & $\begin{array}{l}\text { "What is the relationship between the boy and his } \\
\text { mother like? What evidence can you find in the film } \\
\text { supporting your opinion?" "What is the difference } \\
\text { between the companion and service animals?" }\end{array}$ \\
\hline Synthesis & $\begin{array}{l}\text { "What could be changed in the boy's house to improve } \\
\text { his life activities?" "How would you design a friendly } \\
\text { house for a disabled person?" "How could the life of the } \\
\text { person with disabilities be improved?" }\end{array}$ \\
\hline Evaluation & $\begin{array}{l}\text { "How can you prove that a person needs a companion } \\
\text { animal?" "What recommendations can you give about } \\
\text { training dogs to serve people with disabilities? }\end{array}$ \\
\hline
\end{tabular}

2. Role-based group work. Group work has significant potential learning benefits (both academic and social) in the ESP classroom such as development of professional knowledge, language, communication, higher-level thinking, self-management skills, motivation and responsibility [19], [20]. In the ESP class, reading activities based on professionrelated texts take a significant place in the content instruction, since texts serve a major source of presenting terminology in the context. Also, the process of reading complex texts on professional topics requires critical thinking activities from students. They need to understand the implied meanings; find out relationships between the facts, focus on specific details; make reasoning and cause-consequences judgments. Group work engages students in collaborative discussion and analysis of what they have read reinforcing their reading, speaking, listening, and writing skills [21].

Working in groups, students functioned more effectively when they performed specific roles in relation to the text. Based on the text, the teachers designed roles for students. There were four essential roles: 1. Word Expert, 2. Text Transformer, 3. Summarizer; 4. Investigator. Also, there were optional roles which were used according to the classroom objectives: 5. Speech Planner, 6. Connector, 7. Grammar Expert, 8. Analyst. 
TABLE II Essential and Optional Roles for Group Work

\begin{tabular}{|c|c|c|}
\hline \multicolumn{2}{|c|}{ Role Name } & \\
\hline \multirow{4}{*}{ 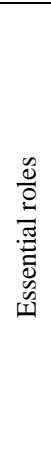 } & $\begin{array}{c}\text { Word } \\
\text { Expert }\end{array}$ & $\begin{array}{l}\text { - Finds and collects profession-related } \\
\text { terminology in the text } \\
\text { - Finds and collects topical words with special } \\
\text { meaning in the text } \\
\text { - Systemizes collected vocabulary }\end{array}$ \\
\hline & $\begin{array}{c}\text { Text } \\
\text { Transformer }\end{array}$ & $\begin{array}{l}\text { - Transforms the information of the text using } \\
\text { different graphic forms (scheme, concept map, } \\
\text { thinking organizer, table) }\end{array}$ \\
\hline & Summarizer & $\begin{array}{l}\text { - Recaps the key points, main highlights, and } \\
\text { general idea of the text }\end{array}$ \\
\hline & Investigator & $\begin{array}{l}\text { - Makes up low- and high-level questions to the } \\
\text { text (comprehension type, explanation type, } \\
\text { description type, evaluation type) } \\
\text { - Analyzes the text through contextual questioning }\end{array}$ \\
\hline \multirow{4}{*}{ 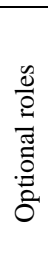 } & $\begin{array}{l}\text { Speech } \\
\text { Planner }\end{array}$ & $\begin{array}{l}\text { - Identifies the main parts of the text } \\
\text { - Makes the plan of the speech about the topic of } \\
\text { the text }\end{array}$ \\
\hline & Connector & $\begin{array}{l}\text { - Connects the facts, ideas of the text to their } \\
\text { personal life experience }\end{array}$ \\
\hline & $\begin{array}{l}\text { Grammar } \\
\text { Expert }\end{array}$ & $\begin{array}{l}\text { - Identifies grammar rules and structures used in } \\
\text { the text }\end{array}$ \\
\hline & Analyst & - Compares and contrasts information in the text \\
\hline
\end{tabular}

The teachers formed the groups of 4-6 students with strong and weak language skills and distributed roles among them according to their language proficiency. All students worked individually with the same text but they did different tasks according to their roles during 40-45 minutes. The other 45-50 minutes of the class work was fixed for presenting results and holding a discussion in the group.

3. The use of thinking maps. Thinking maps designed by David Hyerle are very supportive in learning new vocabulary and developing critical thinking skills [22]. Each map is graphically flexible so that students may expand the map while planning or organizing the specific learning content. Thinking maps were used by the students as tools for reading, writing, and speaking activities. Students learned to choose which maps fitted the immediate learning content and used a combination of maps to reflect it.

4. Creative writing. Good writing skills are an integral part of professional communication skills. The purpose of creative writing is to express personal opinions, thoughts and share experiences. Creative writing assignments such as writing a personal essay, a summary, or a description, etc. involved a planned, purposeful application of appropriate communication and thinking techniques. The students were engaged into 4step management procedure: 1. Before writing (prepared ideas, made a plan); 2. During writing (made a mind map to collect and systemize ideas, vocabulary and grammar structures, linkers); 3. During writing (developed writing); 4. After writing (reviewed and evaluated work, looked for improvement).

During the semester, the students were required to write a personal essay on a profession-related topic ("What are the challenges of being a veterinarian?" "Is becoming a veterinarian doctor difficult?"), a summary of the text and a description of the pet.

\section{RESULTS}

The progress of communication skills in students of the experimental and control groups was assessed through the examination results. At the end of the ESP course, the students passed final Listening and Grammar \&Vocabulary test and completed examination tasks on reading, speaking and writing. The final Grammar \&Vocabulary test was designed by the teachers on the base of the learning materials which were used in the content instruction. Students' listening skills were checked through comprehension questions to a short film "I love my job: Veterinarian" (https://www.youtube.com/watch?v=CRRYLME_pnE\&t=84s). The examination tasks included reading a profession-related text without using a dictionary and a discussion on the topic raised in the text. Writing examination task was to make a written summary of the text. The results of the test and students' performance in the examination are shown in Fig. 1.

The comparative analysis of the students' performance in the Grammar \&Vocabulary part of the test indicated a significant growth of linguistic knowledge in most students by the end of the ESP course with better results in Group 2 Unfortunately, there were a lot of students who demonstrated low level of their listening skills both in Group 1 and 2 though the number of students who succeeded in doing the listening task in the test was bigger in Group 1.



Fig. 1 Performance of the tasks in Group 1 and Group 2 (in percentage

The outcomes of the students' performance in the reading examination task were the most positive: $33 \%$ and $53 \%$ of students in Group 1 and $36 \%$ and $38 \%$ of students in Group 2 achieved average and high levels of reading skills respectively.

Also, the students' results in the speaking part of the examination indicate a better students' performance in communication in the experimental group: $36 \%$ of students in Group 1 against $21 \%$ of students in Group 2 reached the high level in speaking skills. However, $40 \%$ of students in the control group demonstrated poor speaking skills in the exam. As for the writing part of the examination, the big number of students in the both groups performed quite well in the exam though there were $25 \%$ and $29 \%$ of students in Group 1 and 2 who got low scores for the writing examination task. At the same time, the comparative analysis of the students' results in speaking and writing in the experimental group suggests a positive correlation between speaking and writing proficiency. 


\section{DISCUSSION}

The aim of the study was to check the efficiency of thinking-based communicative teaching strategies for developing professional communication skills in veterinary undergraduate students in the ESP class. The findings of this study support the idea that the integration of communicative and critical thinking approach to the ESP instruction helped the students function better in ESP class and get better results at the end of the course.

It was found out that the role-based group work proved to be the most successful and a most popular instructional strategy among students and teachers. Working in groups, students were in the center of the learning process practicing all language skills in a balanced way according to their assigned roles. Most students admitted that they were more productive and felt more comfortable and confident when working in a smaller group. Students with strong and weak language skills had an opportunity to do tasks of different complexity so the group work for all students was challenging. At the same time, students with weaker language skills could capitalize on the expertise of more proficient students when they worked together in the group. For teachers, it was satisfying to see how students grow in their reading and speaking abilities in a true communicative environment.

The teachers' in-class observation and students' responses in the final discussion testified that the use of thinking maps was very supportive in two aspects: memorizing and practicing new professional terminology and organizing ideas about the professional topic. During the course, more and more students used their thinking maps as a communication support when they talked about the topic or worked on a writing assignment. When making thinking maps, some students demonstrated excellent creative and artistic skills.

The findings support the efficiency of creative writing strategy with the impact on the writing communication skills. It is important to mention that those students who worked in a planned way following a 4-step procedure gained better results.

In the ESP class, a guided discussion was a really effective strategy to engage students into intellectual communication, which made an impact on both communication and critical thinking skills though it was a challenging task for teachers to find the right communication stimulus which would be interesting for most of the students, thought provoking and profession-related at the same time. This strategy was especially useful for students who had better language proficiency. They expressed their opinions and felt free in speaking. Those who had weaker language skills were not active participants in the discussion. They felt more confident in a smaller group. We understood the importance of all-level questions not only in relation to critical thinking skills but to the students' language proficiency as well.

On the other hand, the research findings show that the traditional teaching methods such as grammar and vocabulary drills proved to be more beneficial for the mastery of linguistic aspects such as grammar and profession-related terminology.

\section{CONCLUSION}

In the profession of a veterinary doctor, strong professional communication skills are the most useful among other soft skills. Due to read-and-translate teaching tradition in the ESP class in Russian universities, students fail to gain sufficient communication skills. We made an assumption that if the teachers use the special strategies incorporating principles of communicative and critical thinking approaches in the instruction of the ESP course, undergraduate students will be more successful in gaining professional communication skills.

The present study was aimed at checking the efficiency of the four thinking-based communicative teaching strategies: guided discussions, role-based group work, the use of thinking maps, creative writing for developing professional communication skills in veterinary undergraduate students in the ESP class.

The comparative analysis of students' performance in the experimental and control groups in the end-course examination and direct teacher in-class observation allows the conclusion about the efficiency of the implemented strategies in the ESP class.

This study also found a few implications of the implemented strategies. It is found out that if students are equipped with thinking mapping strategy and creative writing 4-step management strategy, they perform better in reading, writing and speaking and they are more organized in learning. The role-based group work proved to be the most effective in relation to practicing reading and speaking skills. Moreover, it was the most popular strategy with the students. Although a guided discussion was a really effective strategy to engage students into intellectual communication, there is still the need for further development in all-level communication engagement of the students.

All in all, the thinking and communicative learning environment created through the use of specially selected instructional strategies served as a key factor in the development of the professional communication skills. The use of guided discussions, role-based group work, thinking maps, creative writing assignments moved the learning process towards the development of the balanced professional communicative skills in reading, listening, speaking and writing. The study revealed that the integration of thinkingbased and communication-based activities involved the students into more intellectual, meaningful, motivating and communicative language learning.

\section{References}

[1] O.A. Kalugina, "Development of students' professional communicative competence in an economic higher school," XLinguae, vol. 9(4), pp. $37-45,2016$

[2] I.V. Kulamikhina, Z.B Esmurzaeva, D.G. Vasbieva, A.Y. Alipichev, "Supporting English competence development in university teachers: principles and practices," New Trends and Issues Proceedings on Humanities and Social Sciences, vol. 6(1), pp 256-268, 07-10 February 2019 [11th World Conf. on Educational Sciences, 2019].

[3] I.V. Kulamikhina, J. Birova, A.Yu. Alipichev, D.G. Vasbieva, O.A Kalugina, "Developing communication and critical thinking through 
creative writing in English and French language: analysis of classroom management strategies," Komunikacie, vol. 20(1), pp. 115-130, 2018

[4] Y.B. Novikova, A.Y. Alipichev, O.A. Kalugina, Z.B. Esmurzaeva, S.G. Grigoryeva, "Enhancement of socio-cultural and intercultural skills of EFL students by means of culture-related extra-curricular events," XLinguae, vol. 11(2), pp. 206-217, 2018.

[5] B.H. Nasrabadi, K. Mousavi, S. Farsan Zabihullah, "Attitude of critical thinking and cognitive learning styles in predicting academic achievement of university students," Iranian Journal of Medical Education, vol. XII (4), pp. 285-296, 2012.

[6] P. Sharma, "A study of learning-thinking style of secondary school students in relation to their academic achievement," International Journal on New Trends in Education and Their Implications, vol. 2(4), pp.115-23, 2011.

[7] Ch. Liu, F. Long, "The Discussion of traditional teaching and multimedia teaching approach in college English teaching", pp. 31-33, January 2014 [International Conference on Management, Education and Social Science, 2014]

[8] D. Larsen-Freeman, M. Anderson, Techniques and Principles in Language Teaching, Oxford: Oxford University Press, 2011.

[9] L. Wei, "Communicative language teaching in EFL contexts: not a universal medicine," Idiom, vol. 41(3), 2011 Retrieved on 10.01.2020 from http://idiom.nystesol.org/articles/vol40-04.html

[10] H. Masduqi, "Critical thinking skills and meaning in English language teaching", TEFLIN Journal, vol. 22(2), pp. 185-201, 2011.

[11] B. Bloom, M. Englehart, E. Furst, W. Hill, D. Krahtwohl, Taxonomy of educational objectives: the classification of educational goals, New York: Longmans Green, 1956.

[12] M. Yusuf, "Infusing thinking-based learning in twenty-first-century classroom: the role of training programme to enhance teachers' skilful thinking skills," Teacher Empowerment Toward Professional Development and Practices: Perspectives across Borders, vol. 4, pp. 211-220, 2017.
[13] H. Brown, Teaching by Principles, NY: Addison Wesley Longman, 2001.

[14] R.M. Gilles, F. Adrian, Cooperative Learning: The Social and Intellectual Outcomes of Learning in Groups, London: Farmer Press, 2003.

[15] D.W. Johnson, "An educational psychology success story: social interdependence theory and cooperative learning," Educational Researcher, vol. 38(5), pp. 365-379, 2009.

[16] R.J. Swartz, A. Costa, B. Kallick, B. Beyer, R. Reagan, ThinkingBased Learning: Activating Students' Potential, Norwood, MA: Christopher-Gordon Publishers, 2007.

[17] R.J. Swartz, D. Parks, Infusing the Teaching of Critical and Creative Thinking in Elementary Instruction, CA: Critical Thinking Books \& Software, 1994.

[18] E. DeBono, The Use of Lateral Thinking, 2nd ed., London: Jonathan Cape, 1990.

[19] N.F. Novitasari, "Collaborative learning in ESP speaking classroom: learners' perceptions and experiences", International Seminar on Language, Education, and Culture, KnE Social Sciences, pp. 309-319, 2019.

[20] N. Davidson, C.H. Major, L.K. Michaelsen, "Small-group learning in higher education-cooperative, collaborative, problem-based, and teambased learning: An introduction by the guest editors," Journal on Excellence in College Teaching, vol. 25(3\&4), pp.1-6, 2014.

[21] P. Anderson, L. Corbett, "Literature Circles for Students with Learning Disabilities," Intervention in School and Clinic, vol. 44(1), pp. 25-33, 2008.

[22] D. Hyerle, A Field Guide to Using Visual Tools, NH: Designs for Thinking, 2000. 